\title{
ANALISA KUAT TEKAN BETON Fc'25 MPa DENGAN PENAMBAHAN ABU BATU DAN SEMEN MORTAR UTAMA TYPE 400
}

\author{
Asrullah $^{1)}$,Diawarman ${ }^{2)}$ Rita Anggrainy ${ }^{3)}$ Kamal Afif $^{4)}$ \\ ${ }^{1), 2), 3)}$ Dosen Program Studi Teknik Sipil Fakultas Teknik Universitas Palembang \\ ${ }^{4)}$ Mahsiswa Program Studi Teknik Sipil Fakultas Teknik Universitas Palembang \\ e-mail: asrull66@yahoo.co.id
}

\begin{abstract}
In simple terms, concrete is formed by hardening a mixture of cement, water, fine aggregate (sand), and coarse aggregate (crushed stone or gravel). Sometimes other ingredients are added to improve the quality of the concrete. Current developments, concrete is the most widely used material in construction in the field of civil engineering, both in buildings, bridges, weirs, and other constructions. The nature of the concrete material, which is very strong to withstand compression, but not strong (weak) to withstand tension. The method used in the design of concrete mix using SNI 03-2834-2000. This research was conducted experimentally in the laboratory. The purpose of this study was to determine the value of the compressive strength of normal concrete, the value of the compressive strength of concrete with the addition of stone ash, the addition of the main cement mortar type 400 and the combination of adding stone ash and the main cement mortar type 400. The compressive strength value of the concrete is planned to be $25 \mathrm{MPa}$ standard. The conclusion is that the compressive strength of normal concrete is $25.16 \mathrm{MPa}$, the greatest compressive strength of concrete with the addition of $6 \%$ stone ash is $26.49 \mathrm{MPa}$, the greatest compressive strength of concrete with the addition of cement mortar type $4006 \%$ is $27.57 \mathrm{MPa}$ and The compressive strength of concrete with a combination of the addition of stone ash and the main cement mortar type $4006 \%$ is $27.97 \mathrm{MPa}$. While the simple linear regression model has a strong relationship between the independent variable $(\mathrm{X})$ and the bound variable $(\mathrm{Y})$ with the coefficient of determination $\left(\boldsymbol{R}^{2}\right)$ greater than 0.950 for all compressive strength values.
\end{abstract}

Keywords: compressive strength, stone ash, main cement mortar type 400, linear regression

\begin{abstract}
Abstrak
Secara sederhana, beton dibentuk oleh pengerasan campuran antara semen, air, agregat halus (pasir), dan agregat kasar (batu pecah atau kerikil). Kadang-kadang ditambah bahan lain untuk memperbaiki kualitas beton. Perkembangan sekarang ini, beton merupakan bahan yang paling banyak dipakai pada pembangunan dalam bidang teknik sipil, baik pada bangunan gedung, jembatan, bendung, maupun konstruksi lain. Sifat dari bahan beton, yaitu sangat kuat untuk menahan tekan, tetapi tidak kuat (lemah) untuk menahan tarik. Metode yang digunakan dala desain campuran beton menggunakan SNI 03-2834-2000. Penelitian ini dilakukan eksperimen di laboratorium. Tujuan dari penelitian ini untuk mengetahui nilai kuat tekan beton normal, nilai kuat tekan beton dengan penambahan abu batu, penambahan semen mortar utama type 400 dan kombinasi penambahan abu batu dan semen mortar utama type 400. Nilai kuat tekan beton direncanakan standar $25 \mathrm{MPa}$. Kesimpulan yang dihasilkan adalah nilai kuat tekan beton normal sebesar $25,16 \mathrm{MPa}$, kuat tekan beton terbesar dengan penambahan abu batu $6 \%$ sebesar 26,49 MPa, kuat tekan beton terbesar dengan penambahan semen mortar utama type $4006 \%$ sebesar 27,57 MPa dan kuat tekan beton dengan kombinasi penambahan abu batu dan semen mortar utama type $4006 \%$ sebesar 27,97 MPa. Sedangkan model hubungan regresi linier sederhana mempunyai hubungan yang kaut antara variabel bebas $(\mathrm{X})$ dengan variaber erikat (Y) dengan koefisien determinasinya $(\boldsymbol{R})$ lebih besar dari 0,950 untuk seluruh nilai kuat tekan.
\end{abstract}

Kata Kunci : kuat tekan, abu batu, semen mortar utama type 400, regresi linier 


\section{PENDAHULUAN}

Perkembangan sekarang ini, beton merupakan bahan yang paling banyak dipakai pada pembangunan dalam bidang teknik sipil, baik pada bangunan gedung, jembatan, bendung, maupun konstruksi lain. Penelitianpenelitian telah banyak dilakukan untuk memperoleh suatu penemuan alternatif penggunaan konstruksi karenabeton merupakan unsur yang sangat penting, mengingat fungsinya sebagai salah satu pembentukstruktur yang paling banyak digunakan oleh masyarakat. Penelitian tentang abu batu Asrullah [1] terjadi peningkatan kuat tekan beton dengan penambahan abu batu dan mempunyai keterkaitan yang kuat dengan nilai koefisien determinasi $\mathrm{R}^{2}$ dengan 0,937.

Hasil penelitian yang dilakukan Fitria Handayani [2] memberikan beberapa kesimpulan yaitu penggunaan abu batu sebagai filler dalam produksi SCC dapat meningkatkan kuat tekan beton sebesar 3,5, pada penambahan abu batu dengan takaran 255 berat semen, sedangkan penggunaan abu batu sebagai filler dengan cara substitusi cenderung mengurangi kekuatan tekan SCC. Kesimpulan yang lain penggunaan abu batu sebagai agregat halus pengganti pasir pada campuran pembuatan beton $f c 20 \mathrm{MPa}$ komposisi abu batu harus kurang dari $20 \%$ karena menyebabkan penurunan kuat tekan beton.

Penelitian yang dilakukan oleh Triaswati M.N [3] terjadi peningkatan kuat tekan beton dengan penambahan abu batu pada setiap komposisi campuran. Untuk penelitian yang menggunakan semen mortar utama dengan type 420 pernah dilakukan oleh Asrullah [4] dengan kesimpulannya dapat memberikan pengaruh peningkatan kuat tekan beton dengan adanya penambahan semen mortar utama type 420 . Penelitian dengan menggunakan semen mortar utama type 400 telah dilakukan dalam bentuk mortar oleh Asrullah [5] dimana pada kesimpulannya dapat meningkatkan kuat mortar lebih besar dari mortar standar.

\section{KAJIAN PUSTAKA}

\subsection{Bahan Susunan Beton}

Secara sederhana, beton dibentuk oleh pengerasan campuran antara semen, air, agregat halus (pasir), dan agregat kasar (batu pecah atau kerikil). Kadang-kadang ditambah bahan lain untuk memperbaiki kualitas beton.
Sifat dari bahan beton, yaitu sangat sangat kuat untuk menahan tekan, tetapi tidak kuat (lemah) untuk menahan tarik [6].

Beton Normal diperoleh dengan cara mencampurkan semen portland, air, dan agregat, adapun untuk beton khusus (selain beton normal) ditambahkan bahan tambahan, misalnya pozolan, bahan kimia pembantu, serat, dan sebagainya. Tujuan pemberian bahan tambahan ialah untuk menghasilkan beton khusus yang lebih baik dari beton normal [7].

\subsection{Abu Batu}

Abu batu merupakan hasil penggerusan dari produksi batu pecah. Abu batu merupakan abu yang mengandung banyak silika, alumina dan mengandung senyawa alkali, besi, dan kapur walaupun dalam kadar yang rendah. Dari setiap daerah, komposisi abu batu digunakan dalam adukan beton terutama untuk memperbaiki sifat dari beton [8]. Abu batu dalam penelitian ini mengguanakan abu batu batu yang berasal dari PT. Komba Mahaka Utama desa Lingut OKUT.

\subsection{Semen Mortar Utama Type 400}

Semen Mortar Utama (MU) di produksi oleh PT Cipta Mortar Utama yang merupakan perusahaan nasional terbesar dan pertama yang memproduksi semen instan siap pakai (premixed mortar) dengan menggunakan teknologi modern yang dikenal dengan merek MORTAR UTAMA (MU), Fungsi utama mortar adalah menambah lekatan dan ketahanan ikatan dengan bagian-bagian penyusun suatu konstruksi. Bahan pengisi (filler) yang terkandung didalamnya Guna meningkatkan kepadatan serta mengurangi porositas bahan adukan, sedangkan Bahan tambah (additive) yang terkandung didalam adalah Bahan larut air yang berguna untuk meningkatkan kelecakan (konsistensi), daya ikat, water retention, keawatan \& kekuatan [9].

\section{METODELOGI PENELITIAN}

Penelitian ini dilakukan secara eksprimen di laboratorium Fakultas Teknik Universitas Palembang Metode yang digunakan dala desain campuran beton menggunakan SNI 03-28342000 [10] benda uji bentuk silinder denngan diameter $15 \mathrm{~cm}$ dan tinggi $30 \mathrm{~cm}$. Pemeriksaan Karakteristik material dilakukan sesuai dengan standar yang berlaku. Benda uji dengan penambahan abu batu sebagai pengganti dari berat pasir dalam campuran beton normal 
sebesar persentasi masing-masing campuran, sedangkan untuk benda uji penambahan semen mortar utama type 400 dari berat semen dan tidak mengurangi berat semen yang dibutuhkan dalam campuran beton normal. Faktor air semen disesuaikan dengan kebutuhan masingmasing komposisi campuran. Benda uji dibuat sesuai dengan kebutuhan pengujian kuat tekan betonyang terdiri dari sebagai berikut.

1. Beton normal (BN)

2. Beton dengan penambahan abu batu $2,0 \%$ (BAB 1)

3. Beton dengan penambahan abu batu $4,0 \%$ (BAB 2)

4. Beton dengan penambahan abu batu $6,0 \%$ (BAB 3)

5. Beton dengan penambahan semen mortar utama type 400 2,0\% (BSMU 1)

6. Beton dengan penambahan semen mortar utama type 400 4,0\% (BSMU 2)

7. Beton dengan penambahan semen mortar utama type $4006,0 \%$ (BSMU 3)

8. Beton dengan kombinasi penabahan abu batu +semen mortar utama type $4002,0 \%$ (BASMU 1)

9. Beton dengan kombinasi penabahan abu batu +semen mortar utama type $4004,0 \%$ (BASMU 2)

10.Beton dengan kombinasi penabahan abu batu +semen mortar utama type $4006,0 \%$ (BASMU 3)

Pengujian kuat tekan beton umur 7,14,21 dan 28 hari dengan metode SNI 1974-2011 [11]. Untuk mengetahui hubungan antara penambahan abu batu dan semen mortar utama dilakukan analisa regresi linier sederhana dengan variabel bebas (X) penambahan abu batu dan variabel terikat (Y) kuat tekan beton [4]. Bagan alir penelitian dapat dilihat pada gambar 1 berikut ini:

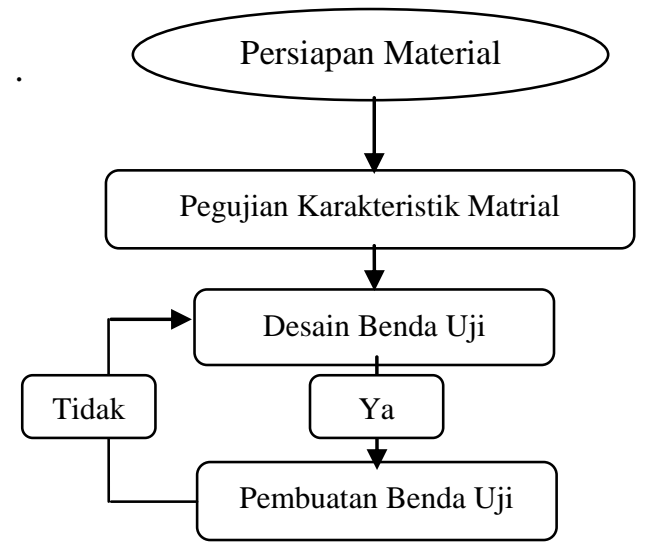

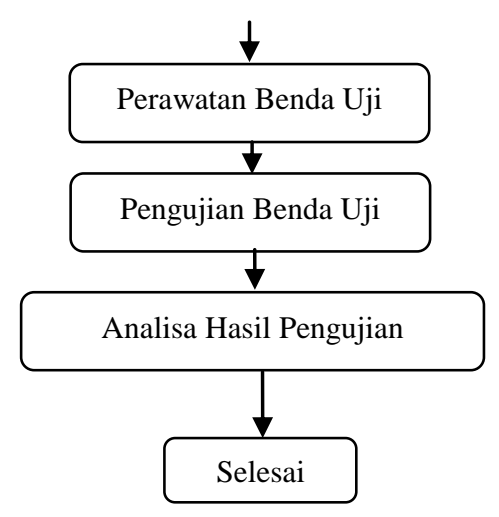

Gambar 1. Bagan Alir Penelitian

\section{HASIL DAN PEMBAHASAN \\ 4.1. Hasil Pengujian Kuat Tekan}

Hasil pengujian kuat tekan beton pada umur 28 hari setiap campuran disajikan dalam tabel 1,2 dan 3 berikut ini;

\section{Tabel 1. Kuat Tekan Beton Normal Dan Beton Dengan Penambahan Abu Batu Pada Umur 28}

\begin{tabular}{clc}
\hline No & \multicolumn{1}{c}{ Jenis Beton } & $\begin{array}{c}\text { Kuat Tekan } \\
\text { (MPa) }\end{array}$ \\
\hline 1 & $\begin{array}{l}\text { Beton normal (BN) } \\
\text { Beton dengan Penabahan }\end{array}$ & 25,16 \\
& $\begin{array}{l}\text { Abu Batu 2,0\% (BAB 1) } \\
\text { Beton dengan Penabahan } \\
\text { abu batu 4,0\% (BAB 2) }\end{array}$ & 25,66 \\
4 & $\begin{array}{l}\text { Beton dengan Penabahan } \\
\text { abu batu 6,0\% (BAB 3) }\end{array}$ & 25,93 \\
\hline
\end{tabular}

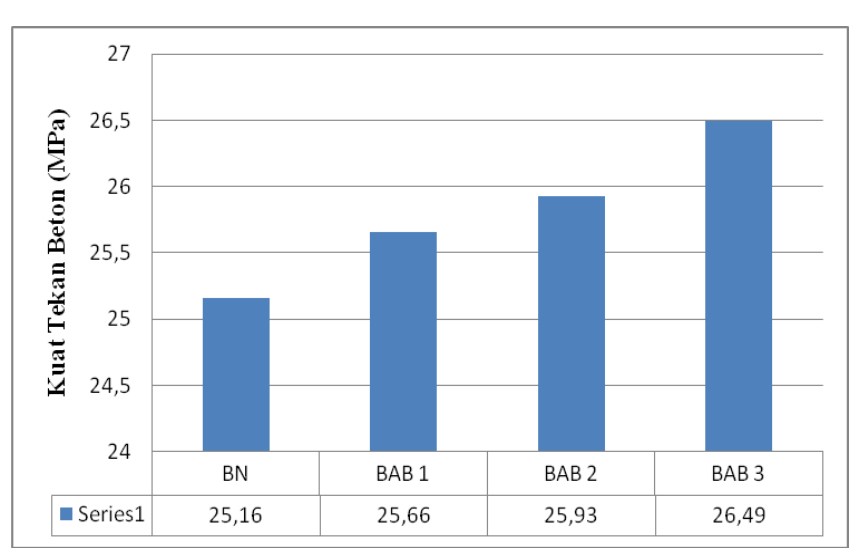

Gambar 2. Kuat Tekan Beton Normal Dan Beton Dengan Penambahan Abu Batu Pada Umur 28 
Hasil pada tabel 1, kuat tekan beton normal $(\mathrm{BN})$ sebesar 25,16 MPa memenuhi syarat dari beton normal $(\mathrm{BN})$ yang di desain. Beton dengan penambahan abu batu 2,0\% (BAB 1) nilai kuat tekannya 25,66 MPa lebih besar dari beton normal (BN), untuk penambahan abu batu 4,0\% (BAB 2) nilai kuat tekanya $25,93 \mathrm{MPa}$ dan penambahan abu batu $6,0 \%$ nilai kuat tekanya 26,49 $\mathrm{MPa}$.

Dari hasil yang ada dapat disimpulkan bahwa dengan penambahan abu batu terjadi kenaikan nilai kuat tekan namun tidak terlalu signifikan. Hasil ini sesuai dengan hasil penelitian [1] dan hasil penelitian [3] penggunaan abu batu sebagai bahan tambah pada beton akan meningkatkan kuat tekan beton sebesar jika dibandingkan dengan kuat tekan beton yang tidak menggunakan abu batu. Sedangkan hasil penelitian [2] memberikan kesimpulan penambahan abu batu sebagai pengganti pasir dapat meningkatkan nilai kuat tekan tetapi dengan batasan maksimum $20 \%$.

\section{Tabel 2. Kuat Tekan Beton Normal Dan Beton Dengan Penambahan Semen Mortar Utama Type 400 Pada Umur 28}

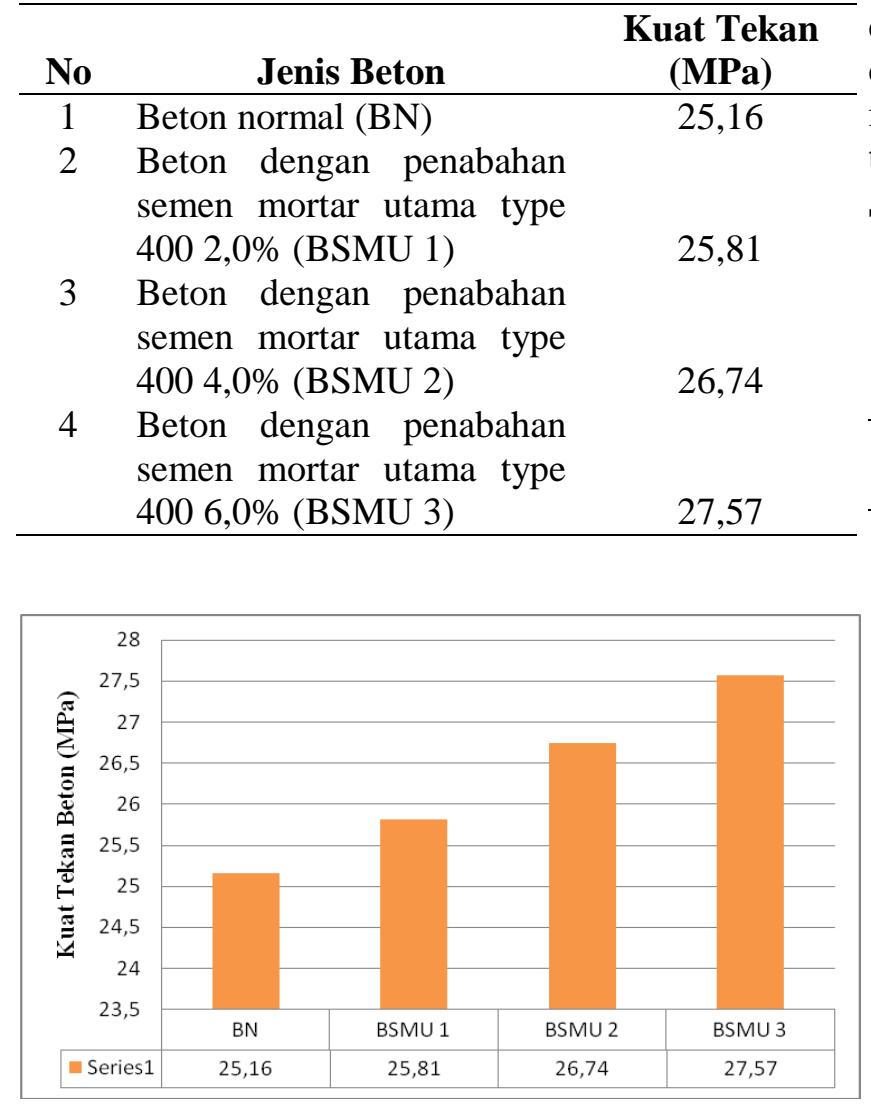

\section{Gambar 3. Kuat Tekan Beton Normal Dan Beton Dengan Penambahan Semen Mortar Utama Type 400 Pada Umur 28}

Hasil yang disajikan pada tabel 2, dapat disimpulkan bahwa dengan bertambahnya semen mortar utama typ3 400 di dalam campuran beton, terjadi peningkatan kuat tekan beton. Nilai kuat tekan beton normal $(\mathrm{BN})$ 25,16 $\mathrm{MPa}$ secara berturut-turut terjadi peningkatan menjadi $25,81 \mathrm{MPa}$ untuk kuat tekan beton dengan penambahan semen mortar utama type 400 2,0\% (BSMU 1), 26,74 MPa untuk kuat tekan beton dengan penambahan semen mortar utama type 400 4,0\% (BSMU2), dan 27,57 MPa untuk kuat tekan beton dengan penambahan semen mortar utama type $4006 \%$ (BSMU 3), secara keseluruhan nilai kuat tekan beton dengan penambahan semen mortar utama type 400 (BSMU) lebih besar dari kuat tekan beton dengan penambahan abu batu..

Dari hasil ini terjadi peningkatan namun tidak signifikan, peningkatan ini terjadi karena semen mortar utama type 400 ada unsur zat additive didalamnya [9]. Hal ini juga diperkuat dengan hasil penelitian [2] namun dalam bentuk mortar. Dalam penelitian lainnya dengan menggunakan semen mortar utama dengan type lain yaitu type 420 [4] menyimpulkan terjadi kenaikan nilai kuat tekan beton dengan benda uji berbentuk kubus.

Tabel 3. Kuat Tekan Beton Normal Dan Beton Dengan Kombinas Penambahan Abu Batu Semen Mortar Utama Type 400 Pada Umur 28

\begin{tabular}{|c|c|c|}
\hline No & Jenis Beton & $\begin{array}{c}\text { Kuat Tekan } \\
\text { (MPa) }\end{array}$ \\
\hline 1 & Beton normal (BN) & 25,16 \\
\hline 2 & $\begin{array}{l}\text { Beton dengan kombinasi } \\
\text { penabahan abu batu }+ \text { semen } \\
\text { mortar utama type } 4002,0 \% \\
\text { (BASMU 1) }\end{array}$ & 25,66 \\
\hline 3 & $\begin{array}{lrr}\text { Beton dengan kombinasi } \\
\text { penabahan abu } & \text { batu+ } \\
\text { penabahan semen } & \text { mortar } \\
\text { utama type } 400 & 4,0 \% \\
\text { (BASMU 2) } & \end{array}$ & 27,33 \\
\hline 4 & $\begin{array}{l}\text { Beton dengan kombinasi } \\
\text { penabahan abu batu }+ \text { semen } \\
\text { mortar utama type } 4006,0 \% \\
\text { (BASMU 3) }\end{array}$ & 27,97 \\
\hline
\end{tabular}



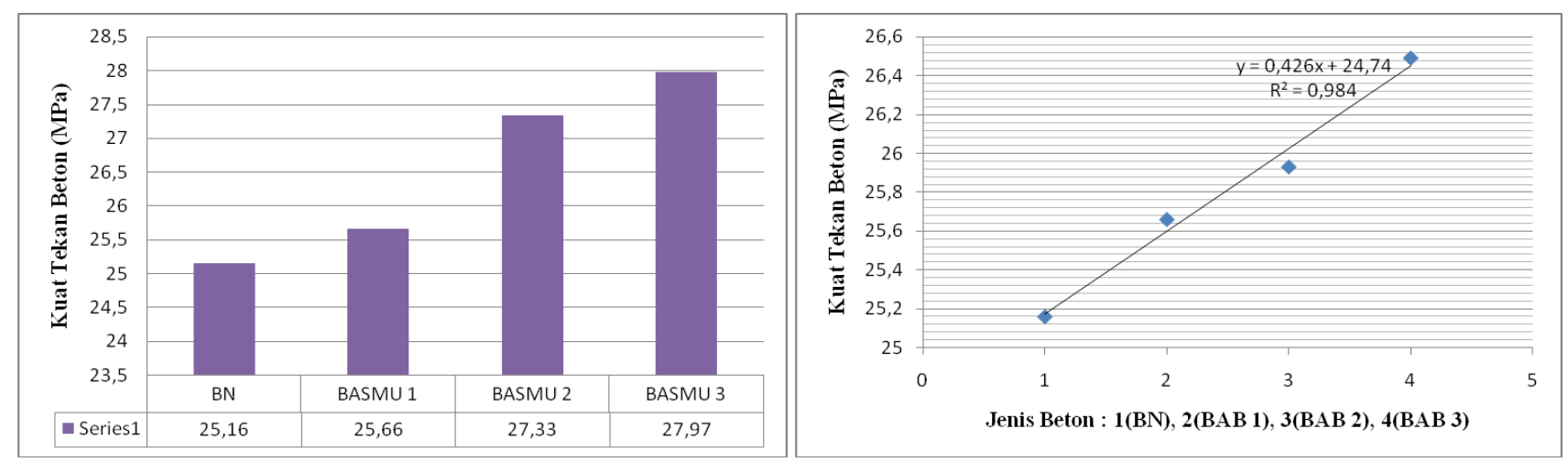

\section{Gambar 4. Kuat Tekan Beton Normal Dan Beton Dengan Kombinas Penambahan Abu Batu + Semen Mortar Utama Type 400 Pada Umur 28}

Nilai kuat tekan yang disajikan dalam tabel 3 untuk beton normal (BN) sebesar 25,16 MPa, beton dengan kombinasi penabahan abu batu + semen mortar utama type 400 2,0\% (BASMU 1) dengan nilai $25,66 \mathrm{MPa}$, beton dengan kombinasi penabahan abu batu+ penabahan semen mortar utama type 400 4,0\% (BASMU 2) dengan nilai $27,33 \mathrm{MPa}$, beton dengan kombinasi penabahan abu batu +semen mortar utama type $4006,0 \%$ (BASMU 3) sebesar 27,97 MPa.

Secara keseluruhan campuran kombinasi ini terjadi kenaikan namun tidak signifikan juga, akan tetapi nilai kuat tekannya melebihi nilai kuat tekan dengan beton penambahan abu batu (BAB) maupun beton dengan penambahan semen mortar utama type 400 (BSMU).

\subsection{Model Hubungan Regresi Linier Sederhana}

Analisa regresi linier sederhana dilakukan untuk memperoleh suatu model regresi yang menggambarkan hubungan antara suatu variabel bebas (X) (penambahan abu batu) dan suatu variabel terikat (Y) kuat tekan beton. Hasil Analisa regresi disajikan pada gambar 5,6 dan 7 berikut ini.

\section{Gambar 5. Hubungan Nilai Kuat Tekan Beton Dengan Penambahan Abu Batu (BAB)}

Model regresi pada Gambar 5 adalah regresi linier sederhana yang merupakan hubungan antara nilai kuat tekan beton dengan penambahan abu batu dengan persamaan $\mathrm{Y}=$ $0,426 x+24,74$. Dari persamaan ini terlihat bahwa nilai positif Asrullah [4] pada koefisien regresi menunjukkan angka peningkatan variabel terikat $(\mathrm{Y})$ yang didasarkan pada variabel bebas $(\mathrm{X})$.

Artinya jika penambahan abu batu meningkat, maka akan menyebabkan peningkatan nilai kuat tekan beton. Selanjutnya menurut Asrullah [4] koefisien determinasi $\boldsymbol{R}^{2}$ bernilai 0,984 , berarti memeliki keterkaitan yang kuat antara penambahan abu batu dan nilai kuat tekan beton. Selain itu koefisien tersebut memperlihatkan bahwa pengaruh penambahan abu batu terhadap nilai kuat tekan beton sebesar $98,40 \%$.

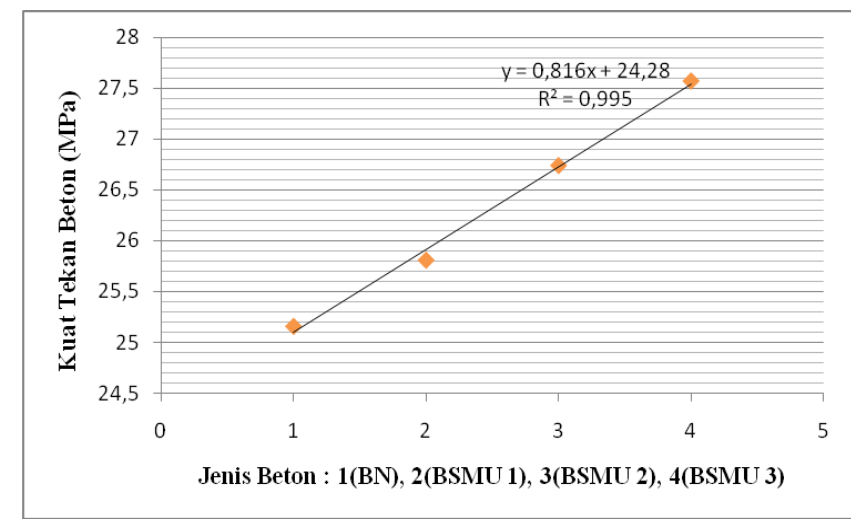

Gambar 6. Hubungan Nilai Kuat Tekan Beton Dengan Penambahan Semen Mortar Utama Type 400 (BSMU) 
Model regresi pada Gambar 6 adalah regresi linier sederhana yang merupakan hubungan antara nilai kuat tekan beton dengan penambahan Abu Batu dengan persamaan $\mathrm{Y}=$ $0,816 x+24,28$. Dari persamaan ini terlihat bahwa nilai positif Asrullah [4] pada koefisien regresi menunjukkan angka peningkatan variabel terikat $(\mathrm{Y})$ yang didasarkan pada variabel bebas $(\mathrm{X})$.

Artinya jika penambahan semen mortar utama type 400 meningkat, maka akan menyebabkan peningkatan nilai kuat tekan beton. Selanjutnya menurut Asrullah [4] koefisien determinasi $\boldsymbol{R}^{2}$ bernilai 0,995, berarti memeliki keterkaitan yang kuat antara penambahan semen mortar utama type 400 dan nilai kuat tekan beton. Selain itu koefisien tersebut memperlihatkan bahwa pengaruh penambahan Abu Batu terhadap nilai kuat tekan beton sebesar $99,50 \%$.

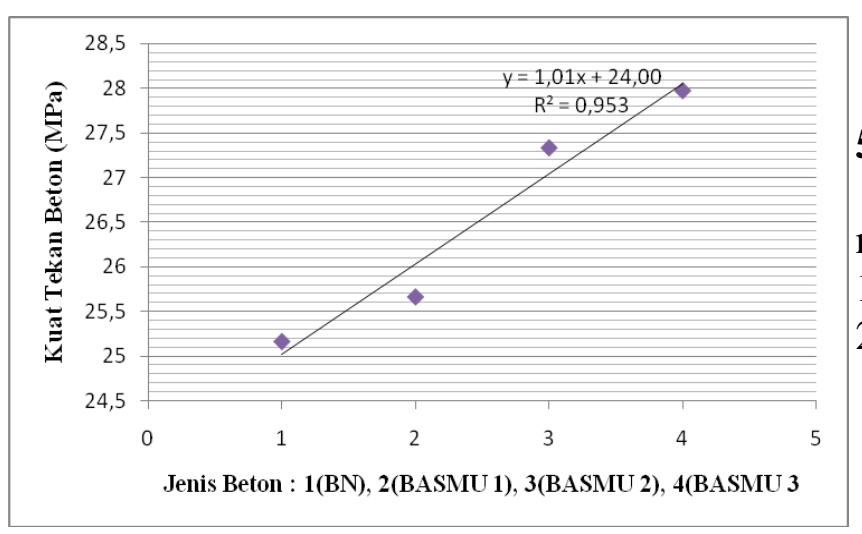

\section{Gambar 7. Hubungan Nilai Kuat Tekan Beton Kombinas Penambahan Abu Batu + Semen Mortar Utama Type 400}

Model regresi pada Gambar 7 adalah regresi linier sederhana yang merupakan hubungan antara nilai kuat tekan beton dengan penambahan Abu Batu dengan persamaan $\mathrm{Y}=$ $1,01 \mathrm{x}+24,00$. Dari persamaan ini terlihat bahwa nilai positif Asrullah [4] pada koefisien regresi menunjukkan angka peningkatan variabel terikat (Y) yang didasarkan pada variabel bebas $(\mathrm{X})$.

Artinya jika penambahan semen mortar utama type 400 meningkat, maka akan menyebabkan peningkatan nilai kuat tekan beton. Selanjutnya menurut Asrullah [4] koefisien determinasi $\boldsymbol{R}^{2}$ bernilai 0,953, berarti memeliki keterkaitan yang kuat antara penambahan semen mortar utama type 400 dan nilai kuat tekan beton. Selain itu koefisien tersebut memperlihatkan bahwa pengaruh penambahan Abu Batu terhadap nilai kuat tekan beton sebesar 95,30\%.

\section{KESIMPULAN DAN SARAN \\ 5.1. Kesimpulan}

Dari hasil penelitian ini dapat disimpulkan sebagai berikut.

1. Nilai kuat tekan beton Normal sebesar 25, $16 \mathrm{MPa}$ memenuhi standar perencanaan yaitu $25 \mathrm{MPa}$.

2. Nilai kuat tekan beton terbesar dengan penambahan abu batu $6 \%$ (BAB 3) sebesar $26,49 \mathrm{MPa}$

3. Nilai kuat tekan beton terbesar dengan penambahan semen mortar utama type 400 6\% (BSMU 3) sebesar 27,57 MPa

4. Nilai kuat tekan beton dengan kombinasi penambahan abu batu+semen mortar utama type $4006 \%$ (BASMU 3) sebesar 27,97 MPa.

\subsection{Saran-saran}

Dari hasil yang ada, maka peneliti memberikan saran-saran sebagai berikut :

1. Perlu dilakukan penelitian lanjutan

2. Dalam penelitian lanjutan sebaiknya dilakukan dengan penamahan persentase jumlah abu batu dan semen mortar utama type 400 untuk campuran beton yang lebih tinggi lagi.

\section{DAFTAR PUSTAKA}

[1] Asrullah, Cecep Irwansyah, Mupli 2020, Pengaruh Penambahan Limbah Abu Batu Terhadap Kuat Tekan Beton $f_{c}$ '20 MPa dengan Menggunakan Gradasi Split Berbeda Jurnal Teknik Sipil Vol 10 No 2(2020) ISSN.2089-2942， E-ISSN.2686-6676 DOI:http://doi.org/10.36546/tekniksipi 1.v10i2.483 pp 77-82

[2] Fitria Handayani 2019, Manfaat Limbah Abu Batu Sebagai Tambahan Material Bahan Bangunan. Seminar Nasional Tahunan VI Program Studi Magister Teknik Sipil ULM Banjarmasin, 26 Oktober 2019

[3] Triaswati M.N, Didik Harijanto, Boedi Wibowo \& Wahyu Ismoyo, 2019 Use of Rock Ash to Reduce Natural Sand Aggregates in Concrete Mixes by 
Adding Type D Additive Substances Departemen Teknik Infrastruktur Sipil, Fakultas Vokasi, (ITS). Surabaya. (e)ISSN 2615-1847 (p)ISSN 26151839 Jurnal Manajemen Aset Infrastruktur \& Fasilitas, Vol. 3, Edisi Khusus 2, Juni 2019 pp 1-9.

[4] Asrullah and A Mulyadi, 2017. A Study on the Use of Mortar Utama Cement Type 420 as Concrete Admixture. International Conference on Innovative Research ICIR EUROINVENT 2017 IOP Publishing IOP Conf. Series: Materials Science and Engineering 209 (2017) 012088 doi:10.1088/1757899X/209/1/012088.pp.7

[5] Asrullah, Diawarman, Ricky Meiza 2021, Pengaruh Penambahan Abu Batu dan Semen Mortar Utama Type 400 Terhadap Kuat Tekan Mortar Standar fc 4,60 MPa. Jurnal Teknik Sipil Vol 11 No 1 (2021)

ISSN.2089-2942, E-ISSN.2686-6676 DOI:http://doi.org/10.36546/tekniksipi 1.v11i1.471 pp 14-21

[6] Ali Asroni 2010, Balok dan Plat Beton Bertulang Edisi Pertama Cetakan Pertama, Graha Ilmu Yogyakarta ISBN 978-979-756-613-5 pp 2,23

[7] Kardiono Tjokrodimuljo, M.E, 2007. Teknologi Beton, Edisi Pertama, Cetakan pertama Biro penerbit Teknik Sipil dan Lingkungan Universitas Gajah Mada $p p 1$

[8] Tanjung Rahayu Raswitaningrum, Randy Fajar Aris Setiawan, 2019. Pengaruh Abu Batu Terhadap Kuat Tekan Beton Pasca Pembakaran. Seminar Nasional Sains dan Teknologi 2019 Fakultas Teknik Sipil, Universitas Muhammadiyah Jakarta, 16 Oktober 2019. p-ISSN : 2407-1846

e-ISSN : 2460-8416 pp 1-6

[9] http://ptprabuagungperkasa.indonetwork.co. id /4534233/semen-mortar-utamamu.htm di akses 11 Januari 2021

[10] SNI 03-2834-2000, Tata Cara Pembuatan Campuran Beton Normal

[11] SNI 1974-2011, Cara Uji Kuat Tekan Beton Dengan Benda uji 